\title{
ANALYSIS OF CERVICAL SAGITTAL PARAMETERS IN PATIENTS WITH RHEUMATOID ARTHRITIS
}

\author{
ANÁLISE DOS PARÂMETROS SAGITAIS CERVICAIS EM PACIENTES COM ARTRITE \\ REUMATOIDE
}

\author{
ANÁLISIS DE LOS PARÁMETROS SAGITALES CERVICALES EN PACIENTES CON ARTRITIS \\ REUMATOIDE

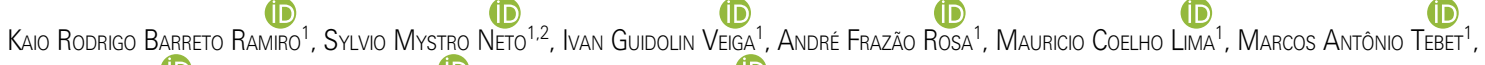 \\ Wagner Pasoualini , Paulo Tadeu Maia Caval ${ }^{1}, 2$, Marcelo ítalo Risso Neto 1,2 \\ 1. Universidade Estadual de Campinas (UNICAMP), Faculdade de Ciências Médicas, Department of Orthopedics and Traumatology, Spine Surgery Group, Campinas, SP, Brazil. \\ 2. Hospital Alemão Oswaldo Cruz, São Paulo, SP, Brazil.
}

\begin{abstract}
Objective: To analyze the cervical sagittal parameters of patients with rheumatoid arthritis (RA) and compare them with the parameters obtained from healthy patients in a sample of the Brazilian population. Methods: Epidemiological data were collected and 72 radiographs of the cervical spine in the sagittal plane were evaluated by measuring the cervical sagittal parameters $\mathrm{COG}$-C7 (distance measured between the center of gravity of the head and the C7 plumb line -cranial offset), C2-C7 lordosis (vertebrae from C2 to C7), T1S (T1 slope), TIA (thoracic inlet angle) and NT (neck tilt). Statistical analysis was performed using the Student's t and chi-square tests. Results: The TIA and NT values in the RA group were $88.8^{\circ} \pm 12.6^{\circ}$ and $54.5^{\circ} \pm 9.3^{\circ}$, respectively, while for the control group, they were $77.7^{\circ} \pm 7.9^{\circ}$ and $50.5^{\circ} \pm 7.7^{\circ}$, respectively, the RA group values being statistically higher than the control group values ( $\mathrm{p}<0.001$ and $p=0.050$, respectively). The values obtained for COG-C7, C2-C7 lordosis and T1S for the RA group were $9.4 \pm 16.4 \mathrm{~mm}, 25^{\circ} \pm$ $22.4^{\circ}$ and $2.6^{\circ} \pm 10.1^{\circ}$, respectively, while for the control group they were $11.8 \pm 17.6 \mathrm{~mm}, 26.8^{\circ} \pm 12.5^{\circ}$ and $30.9^{\circ} \pm 8.4^{\circ}$, respectively. $^{\circ}$ Conclusions: Patients with RA present changes in the thoracic inlet parameters as compared to the control group, with a statistically significant increase in the TIA and NT values, outlining a characteristic compensatory pattern for maintaining cervical sagittal balance. Level of evidence III; Controlled cross-sectional study.
\end{abstract}

Keywords: Postural Balance; Spine; Arthritis, Rheumatoid.

\section{RESUMO}

Objetivo: Analisar os parâmetros sagitais cervicais dos pacientes com artrite reumatoide (AR) e comparar com os parâmetros obtidos de pacientes saudáveis dentro de uma amostra da população brasileira. Métodos: Foram coletados dados epidemiológicos e avaliadas 72 radiografias da coluna cervical no plano sagital, mensurando os parâmetros sagitais cervicais OCG-C7 (distância medida entre o centro de gravidade do crânio e a linha de prumo de C7 - offset craniano), lordose C2-C7 (vértebra de C2 até C7), T1S (inclinação de T1), TIA (ângulo de abertura superior do tórax) e NT (Neck Tilt). A análise estatística foi realizada com os testes $t$ de Student e qui-quadrado. Resultados: Os valores do TIA e do NT no grupo AR foram $88,8^{\circ} \pm 12,6^{\circ}$ e $54,5^{\circ} \pm 9,3^{\circ}$ respectivamente, enquanto para o grupo controle foram $77,7^{\circ}$ $\pm 7,9^{\circ}$ e $50,5^{\circ} \pm 7,7^{\circ}$ respectivamente, com um aumento estatístico dos valores daqueles em relação a estes ( $p<0,001$ e $p=0,050$, respectivamente). Os valores obtidos do OCG-C7, lordose C2-C7 e T1S para o grupo AR foram $9,4 \pm 16,4 \mathrm{~mm}, 25^{\circ} \pm 22,4^{\circ}$ e $32,6^{\circ} \pm 10.1^{\circ}$, respectivamente, enquanto para o grupo controle foram $11,8 \pm 17,6 \mathrm{~mm}, 26,8^{\circ} \pm 12,5^{\circ}$ e $30,9^{\circ} \pm 8,4^{\circ}$, respectivamente. Conclusões: Os pacientes com AR apresentam alterações dos parâmetros do ângulo de abertura superior do tórax em comparação com o grupo controle, com um aumento significativo estatístico dos valores do TIA e NT, esboçando um padrão compensatório característico para manutenção do equilíbrio sagital cervical. Nível de evidência III; Estudo transversal controlado.

Descritores: Equilíbrio Postural; Coluna Vertebral; Artrite Reumatoide.

\section{RESUMEN}

Objetivo: Analizar los parámetros sagitales cervicales de los pacientes con artritis reumatoide (AR) y comparar con los parámetros obtenidos de pacientes saludables dentro de una muestra de la población brasileña. Métodos: Fueron colectados datos epidemiológicos y evaluadas 72 radiografías de la columna cervical en el plano sagital, midiendo los parámetros sagitales cervicales OCG-C7, (distancia medida entre el centro de gravedad del cráneo y la línea de plomo de C7 - offset craneal), lordosis C2-C7, (vértebra de C2 hasta C7), T1S (inclinación de T1), TIA (ángulo de apertura superior del tórax) y NT (Neck Tilt). El análisis estadístico fue realizado con los tests t de Student y chi-cuadrado. Resultados: Los valores del TIA y del NT en el grupo AR fueron $88,8^{\circ} \pm 12,6^{\circ}$ y $54,5^{\circ} \pm 9,3^{\circ}$, respectivamente, mientras que para el grupo control fueron $77,7^{\circ} \pm 7,9^{\circ}$ y $50,5^{\circ} \pm 7,7^{\circ}$, respectivamente, con un aumento estadístico de los valores de aquellos con relación a éstos ( $p<0,001$ y $p=0,050$, respectivamente). Los valores obtenidos del OCG-C7, lordosis C2-C7 y T1S para

Study conducted at the Hospital das Clínicas da Faculdade de Ciências Médicas of the Universidade Estadual de Campinas - HC/FCM/UNICAMP, Campinas, SP, Brasil.

Correspondence: Kaio Rodrigo Barreto Ramiro. Rua Barreto Leme, 1920, Apt 18, Campinas, SP, Brasil. 13025-085. kaiobr@hc.unicamp.br 
el grupo AR fueron $9,4 \pm 16,4 \mathrm{~mm}, 25^{\circ} \pm 22,4^{\circ}$ y $32,6^{\circ} \pm 10,1^{\circ}$, respectivamente, mientras que para el grupo control fueron $11,8 \pm 17,6$ $\mathrm{mm}, 26,8^{\circ} \pm 12,5^{\circ}$ y $30,9^{\circ} \pm 8,4^{\circ}$, respectivamente. Conclusiones: Los pacientes con AR presentan alteraciones de los parámetros del ángulo de apertura superior del tórax en comparación con el grupo control, con un aumento estadísticamente significativo de los valores del TIA y NT, esbozando un patrón compensatorio característico para mantenimiento del equilibrio sagital cervical. Nivel de evidencia III; Estudio transversal controlado.

Descriptores: Equilibrio Postural; Columna Vertebral; Artritis Reumatoide.

\section{INTRODUCTION}

Rheumatoid arthritis (RA) is a chronic systemic inflammatory disease that affects the synovial joints. It can also present through extra-articular manifestations, such as rheumatoid nodules, systemic and metabolic changes such as a low HDL cholesterol level, increased insulin resistance and increased levels of C-reactive protein, for example. ${ }^{1,2}$

RA affects about $1 \%-2 \%$ of the adult population worldwide. It is two times more common in females and it has repercussions for the economic involvement of the patient and of the country. ${ }^{3,4}$ Described for the first time in 1890 by Garrod, involvement of the cervical spine was observed in $34 \%$ of the 500 RA patients evaluated. ${ }^{5}$ The cervical spine is the second most common site of rheumatoid arthritis involvement, present in more than $80 \%$ of patients with this disease. ${ }^{6-8}$

Highly complex, the cervical region is susceptible to a series of disorders and complications that can culminate in an imbalance in cervical sagittal alignment. ${ }^{9}$

Proper spinal sagittal alignment translates into harmony between cervical lordosis, thoracic kyphosis and lumbar lordosis. Its misalignment induces compensatory mechanisms to kick in, generating greater energy expenditure and overloading other musculoskeletal system structures, which results in greater physical limitation, fatigue and pain. ${ }^{10-14}$

In 2012, Lee et al., ${ }^{15}$ demonstrated, through the upper chest opening concept, (thoracic inlet - TI), a significant reciprocal correlation between the cranial parameters (distance measured between the cranial center of gravity and the $\mathrm{C} 7$ plumb line - cranial offset [COG-C7], angle of C0), cervical parameters (C2-C7 angle, C0-C2 angle) and TI parameters (angle of the upper chest opening [TIA], neck tilt [NT] and T1 slope [T1S]) in the maintenance of craniocervical sagittal balance associated with proper physiological posture that involves less energy expenditure.

Although previous studies have shown the impact of some of the parameters used to evaluate cervical sagittal alignment on the indices that measure health related quality of life (HRQOL), such as those measured by the Neck Disability Index (NDI), to date we have no knowledge of any study that correlates the cervical sagittal parameters with RA. ${ }^{5-17}$

The objective of the present study is: (1) to analyze cervical sagittal alignment in patients with RA with cervical involvement, and (2) to compare the sagittal parameters of these patients with those of patients who do not have rheumatoid arthritis in a sample Brazilian population.

\section{METHODS}

This is a retrospective, cross-sectional, controlled study, approved by the Institutional Review Board as number CAAE 26416219.2.0000.5404 and conducted from 2012 to 2014 through the collection of clinical and radiological data.

The study sample consisted of patients over 18 years of age with rheumatoid arthritis with cervical involvement documented in an imaging examination. The control group was made up of individuals without rheumatoid arthritis with radiographic images of the cervical spine. The exclusion criteria were: 1) patients with rheumatoid arthritis without cervical involvement; 2) inadequate radiographic records for the assessment of the cervical sagittal parameters to be studied; 3) patients with cervical fractures; and 4) patients who had undergone prior cervical spine surgery.
From a total of 324 lateral cervical spine radiographs evaluated, only 72 met the study inclusion criteria. Twenty-eight radiographs were of patients with rheumatoid arthritis with cervical involvement and were allocated to the RA group. Forty-four radiographs were from patients without rheumatoid arthritis and made up the control group.

In addition to the sagittal parameters, epidemiological data, such as age and sex, were also collected for evaluation.

The radiographs taken in the lateral incidence, with adequate digital quality, were extracted from the HC-UNICAMP database and the parameters measured and evaluated using Surgimap Spine software (Nemaris Inc. New York, USA) in a standard 1x1 scale for all the images.

Since the patients were no longer in clinical follow-up at the hospital and there was no need to be in contact with them, the signing of the informed consent form was waived.

As described by Lee et al., ${ }^{15}$ we measured the COG-C7 values (defined as the distance between the $\mathrm{C} 7$ plumb line and the center of gravity of the head), the cervical lordosis (the C2-C7 angle, measured from the $\mathrm{C} 2$ to $\mathrm{C} 7$ vertebrae using the Cobb method, is defined as the angle formed between the line tangent to the lower endplate of $\mathrm{C} 2$ and another line tangent to the lower endplate of C7), of the T1 slope (T1S, described as the angle formed between the horizontal plane and the upper endplate of the T1 vertebra - T1UEP), of neck tilt (NT, defined as the angle formed between a line perpendicular to the ground drawn from the most proximal extremity of the sternum and another line connecting the most proximal extremity of the sternum to the T1UEP), and of the upper thoracic inlet angle (TIA, defined as the angle formed by a line from the center of the T1UEP and perpendicular to it and another line that connects the center of the T1UEP to the most proximal region of the sternum).

The values of the sagittal parameters and clinical data of the RA patients were compared to those of the controls. The parameters were evaluated by a trained orthopedist with expertise in measuring the described parameters. IBM-SPSS for Windows version 20.0 software was used to perform the analyses and Microsoft Excel 2003 software was used to tabulate the data. The tests were conducted with a significance level of $5 \%$.

\section{RESULTS}

In the RA group $(n=28)$, there were $23(82.1 \%)$ females and $5(17.9 \%)$ males, ranging from 45 to 84 years of age (mean \pm $\mathrm{SD}=62.2 \pm 11.5)$, while in the control group $(n=44)$, there were 35 (79.5\%) females and $9(20.5 \%)$ males, ranging from 21 to 83 years of age (mean $\pm \mathrm{SD}=56.5 \pm 14.9$ ), showing that there was no statistically significant association of the sex of the patients between the groups, nor was there a statistically significant mean difference in the age of the patients ( $p=0.088$ and $p=0.786$, respectively), as shown in Table 1.

As regards the radiographical parameters, Table 2 shows that, among all the parameters evaluated, the TIA and the NT were statistically greater in the RA group patients than in the control group patients ( $p<0.001$ and $p=0.050$, respectively).

\section{DISCUSSION}

When affected by RA, the cervical spine undergoes changes resulting from a chronic inflammatory process with the formation of pannus, bone erosion, slackening of the ligaments and instability, most often occurring in the occiput-C2 transition region. As a result, 
Table 1. Description of the personal characteristics by group and the statistical test results.

\begin{tabular}{|c|c|c|c|c|}
\hline \multirow[b]{2}{*}{ Variable } & \multicolumn{2}{|c|}{ Group } & \multirow{2}{*}{$\begin{array}{c}\text { Total } \\
\text { (N = 72) }\end{array}$} & \multirow[b]{2}{*}{$\mathbf{p}$} \\
\hline & $\begin{array}{c}\text { Control } \\
(\mathrm{N}=44)\end{array}$ & RA $(N=28)$ & & \\
\hline Age (years) & & & & 0.088 \\
\hline mean \pm SD & $56.5 \pm 14.9$ & $62.2 \pm 11.5$ & $58.7 \pm 13.9$ & \\
\hline median (min.; max.) & $59.5(21 ; 83)$ & $60(45 ; 84)$ & $60(21 ; 84)$ & \\
\hline Sex, n (\%) & & & & $0.786^{*}$ \\
\hline Female & $35(79.5)$ & $23(82.1)$ & $58(80.6)$ & \\
\hline Male & $9(20.5)$ & $5(17.9)$ & $14(19.4)$ & \\
\hline
\end{tabular}

Table 2. Description of the radiographical parameters by group and results of comparisons.

\begin{tabular}{|c|c|c|c|c|}
\hline \multirow{2}{*}{ Variable } & \multicolumn{2}{|c|}{ Group } & Total & \multirow[b]{2}{*}{ p } \\
\hline & Control $(N=44)$ & RA (N $=28)$ & $(N=72)$ & \\
\hline COG-C7 (mm) & & & & 0,560 \\
\hline mean \pm SD & $11.8 \pm 17.6$ & $9.4 \pm 16.4$ & $10.9 \pm 17.1$ & \\
\hline $\begin{array}{c}\text { median } \\
\text { (min.; max.) }\end{array}$ & $10.3(-18.4 ; 77)$ & $7(-28 ; 46)$ & $9.1(-28 ; 77)$ & \\
\hline $\begin{array}{c}\text { C2-C7 } \\
\text { Lordosis }\left({ }^{\circ}\right)\end{array}$ & & & & 0.709 \\
\hline mean \pm SD & $26.8 \pm 12.5$ & $25 \pm 22.4$ & $26.1 \pm 16.9$ & \\
\hline $\begin{array}{c}\text { median } \\
\text { (min.; max.) }\end{array}$ & $28.4(-24.2 ; 46.5)$ & $25.5(-32 ; 71)$ & $27(-32 ; 71)$ & \\
\hline T1 Slope $\left({ }^{\circ}\right)$ & & & & 0.454 \\
\hline mean \pm SD & $30.9 \pm 8.4$ & $32.6 \pm 10.1$ & $31.5 \pm 9$ & \\
\hline $\begin{array}{c}\text { median } \\
\text { (min.; max.) }\end{array}$ & $31(11 ; 46)$ & $34.5(10 ; 56)$ & $31.5(10 ; 56)$ & \\
\hline TIA $\left(^{\circ}\right)$ & & & & $<0.001$ \\
\hline mean $\pm \mathrm{SD}$ & $77.7 \pm 7.9$ & $88.8 \pm 12.6$ & $82 \pm 11.3$ & \\
\hline $\begin{array}{c}\text { median } \\
\text { (min.; max.) }\end{array}$ & 76.9 (61.9; 89.3) & $88.5(66 ; 114)$ & $\begin{array}{c}82.1(61.9 ; \\
114)\end{array}$ & \\
\hline Neck Tilt $\left({ }^{\circ}\right)$ & & & & 0.050 \\
\hline mean \pm SD & $50.5 \pm 7.7$ & $54.5 \pm 9.3$ & $52.1 \pm 8.5$ & \\
\hline $\begin{array}{c}\text { median } \\
\text { (min.; max.) }\end{array}$ & $52.1(31.2 ; 66.1)$ & $55.3(38 ; 72)$ & $52.7(31.2 ; 72)$ & \\
\hline
\end{tabular}

the disease manifests itself as atlantoaxial instability (AAI), basilar invagination (BI) and/or subaxial subluxation (SS). ${ }^{18-23}$

The morbidity and mortality resulting from the inflammatory changes of RA in the cervical region are known, but there has been little focus on the cervical sagittal alignment of these patients. In a study to evaluate the morbidity rate in a group of 532 patients diagnosed with RA associated with cervical involvement, Paus et al., ${ }^{24}$ identified $53 \%$ of the deaths from complications related to RA, as well as a significant reduction in life expectancy in both sexes when compared to the normal population.

In our study, the cervical sagittal parameters of the RA group had higher mean values (with the exception of COG-C7, which was lower in this group) than those found for a Korean population of asymptomatic young adults ${ }^{15}$ and for an American population of volunteers. ${ }^{25}$ In addition to the cervical involvement from RA, factors like age, sex and ethnicity also may be responsible for the difference between the values.

The TIA values were statistically higher in the RA group compared to the control group, although there was no significant proportional increase in T1S or C2-C7 lordosis observed in that group.

In 2012, Lee et al., ${ }^{15}$ postulated that the skull and the cervical spine have their own mechanisms for preserving physiological sagittal alignment and that they are more influenced by the TI than by thoracic kyphosis. Thus, they introduced the concept of $\mathrm{Tl}$ and its parameters, in which the shape and orientation of the TI can influence the sagittal alignment of the skull and the cervical spine to maintain a horizontal view, similar to the influence of pelvic incidence $(\mathrm{PI})$ on the pelvis. Through the formula TIA $=\mathrm{T} 1 \mathrm{~S}+\mathrm{NT}$, they concluded that when the TIA is increased, a compensatory increase in the T1S, and consequently in C2-C7 lordosis, is expected in order to maintain a physiological NT, a horizontal view and cervical sagittal alignment with a minimum of energy expended. They also identified the TIA and the T1S as predictive parameters of physiological sagittal alignment.

The direct relationship between sagittal alignment of the high cervical spine with the low cervical spine through the correlation between the C0-C2 angles with the C2-C7 angles, ${ }^{15,25-28}$ and of the $\mathrm{TI}$ parameters with the cervical spine through the angles of the T1S with C2-C7 and of the TIA with the T1S and C2-C7, ${ }^{15,26}$ have been the subject of several studies and are well established in the literature. There is a link between the parameters, where an increase in C0-C2 lordosis induces a decrease in C2-C7 lordosis, an increase in T1S generates an increase in C2-C7 lordosis, and an increase in TIA tends to promote an increase in T1S and C2-C7 lordosis. The inverse relationship is also true for each of the cases mentioned above.

Another parameter that increased significantly in the RA group compared to the control group in our study was the NT. Taken as the angle that evaluates the TI plane (whether it is more horizontal or vertical), the NT was described with a value of around $44^{\circ}$ in the orthostatic position to maintain adequate cervical sagittal alignment with less energy expended. ${ }^{15}$

Just as the importance of the spinopelvic parameters in maintaining adequate sagittal alignment of the spine is based on the directly proportional relationship of pelvic incidence with pelvic version and sacral inclination, ${ }^{29-32}$ craniocervical sagittal balance is greatly influenced by the TI parameters, where the TIA is directly proportional to the sum of T1S and NT. This relationship may explain the findings of this study.

Being a constant value for each individual that does not change according to positioning, ${ }^{15,26}$ once the TIA presents a high value it should induce a proportional increase in the T1S as an adaptive response aimed at keeping the NT close to a physiological value and maintaining cervical sagittal balance. In the RA group, however, this was not the response we observed. To the contrary, there was a significant increase in the NT values in order to maintain the relationship of the TIA with the T1S and the NT parameters, as previously described.

This study has limitations, among them the small sample. Another limitation is based on the fact that the study is focused on the evaluation of imaging findings, and does not consider the clinical conditions presented by the patients in the RA group. Future studies should include and relate overall sagittal parameters, evaluating the involvement of RA in spinal and extraspinal joints.

\section{CONCLUSION}

It was found that patients with RA with cervical involvement present changes of the thoracic inlet parameters when compared with the control group, with a significant increase in TIA and NT values, outlining a characteristic compensatory pattern for maintaining cervical sagittal balance.

All authors declare no potential conflict of interest related to this article. 


\section{REFERENCES}

1. Smolen JS, Aletaha D, Mclnnes IB. Rheumatoid arthritis. Lancet. 2016;388(10055):202338. doi: 10.1016/S0140-6736(16)30173-8.

2. Mclnnes IB, Schett $G$. Pathogenetic insights from the treatment of rheumatoid arthritis. Lancet. 2017;389(10086):2328-37. doi: 10.1016/S0140-6736(17)31472-1.

3. Cross M, Smith E, Hoy D, Carmona L, Wolfe F, Vos T, et al. The global burden of rheumatoid arthritis: estimates from the Global Burden of Disease 2010 study. Ann Rheum Dis. 2014;73(7):1316-22. doi: 10.1136/annrheumdis-2013-204627.

4. Sokka T, Kautiainen H. Pincus T, Verstappen SMM, Aggarwal A, Alten R, et al. Work disability remains a major problem in rheumatoid arthritis in the 2000s: data from 32 countries in the QUEST-RA Study. Arthritis Res Ther. 2010;12(2):R42. doi: 10.1186/ar2951.

5. Pellicci PM, Ranawat CS, Tsairis P, Bryan WJ. A prospective study of the progression of rheumatoid arthritis of the cervical spine. J Bone Joint Surg Am. 1981;63(3):342-50.

6. Murray CJL, Vos T, Lozano R, Naghavi M, Flaxman AD, Michaud C, et al. Disability-adjusted life years (DALYs) for 291 diseases and injuries in 21 regions, 1990-2010: a systematic analysis for the Global Burden of Disease Study 2010. Lancet. 2012;380(9859):2197-223. doi: 10.1016/S0140-6736(12)61689-4.

7. Gillick JL, Wainwright J, Das K. Rheumatoid Arthritis and the Cervical Spine: A Review on the Role of Surgery. Int J Rheumatol. 2015;2015:252456. doi: 10.1155/2015/252456.

8. Neva MH, Hakkinen A, Makinen H, Hannonen P, Kauppi M, Sokka T. High prevalence of asymptomatic cervical spine subluxation in patients with rheumatoid arthritis waiting for orthopaedic surgery. Ann Rheum Dis. 2006:65(7):884-8. doi: 10.1136/ard.2005.042135.

9. Ames CP, Blondel B, Scheer JK, Schwab FJ, Le Huec JC, Massicotte EM, et al. Influence of spinal deformity on management and Outcome of cervical spondylotic myelopathy - Cervical radiographical alignment: Comprehensive assessment techniques and potential importance in cervical myelopathy. Spine (Phila Pa 1976). 2013;38(22 Suppl 1):149-60. doi: 10.1097/ BRS.0b013e3182a7f449.

10. Vialle R, Levassor N, Rillardon L, Templier A, Skalli W, Guigui P. Radiographic analysis of the sagittal alignment and balance of the spine in asymptomatic subjects. J Bone Joint Surg Am. 2005:87(2):260-7. doi: 10.2106/JBJS.D.02043.

11. Lafage V, Schwab F, Skalli W, Hawkinson N, Gagey PM, Ondra S, et al. Standing Balance and sagittal plane spinal deformity: analysis of spinopelvic and gravity line parameters. Spine (Phila Pa 1976). 2008;33(14):1572-8. doi: 10.1097/BRS.0b013e31817886a2.

12. Le Huec JC, Saddiki R, Franke J, Rigal J, Aunoble S. Equilibrium of the human body and the gravity line: the basics. Eur Spine J. 2011;20 (Suppl 5):558-63. doi: 10.1007/s00586011-1939-7.

13. Cheng J, Liu P, Sun D, Ma Z, Liu J, Wang Z, et al. Correlation of cervical and thoracic inlet sagittal parameters by MRI and radiography in patients with cervical spondylosis. Medicine (Baltimore). 2019;98(7):e14393. doi: 10.1097/MD.0000000000014393.

14. Weng C, Wang J, Tuchman A, Wang J, Fu C, Hsieh PC, et al. Influence of T1 Slope on the Cervical Sagittal Balance in Degenerative Cervical Spine. Spine (Phila Pa 1976). 2016;41(3):185-90. doi: 10.1097/BRS.0000000000001353.

15. Lee SH, Kim KT, Seo EM, Suk KS, Kwack YH, Son ES. The Influence of Thoracic Inlet Alignment on the Craniocervical Sagittal Balance in Asymptomatic Adults. J Spinal Disord Tech. 2012;25(2):E41-7. doi: 10.1097/BSD.0b013e3182396301.

16. Tang JA, Scheer JK, Smith JS, Deviren V, Bess S, Hart RA, et al. The Impact of Standing
Regional Cervical Sagittal Alignment on Outcomes in Posterior Cervical Fusion Surgery Neurosurgery. 2012:71(3):662-9. doi: 10.1227/NEU.0b013e31826100c9.

17. Iyer S, Nemani VM, Nguyen J, Elysee J, Burapachaisri A, Ames CP, et al. Impact of Cervical Sagittal Alignment Parameters on Neck Disability. Spine (Phila Pa 1976). 2016;41(5):371-7. doi: 10.1097/BRS.0000000000001221.

18. Joaquim AF, Appenzeller S. Cervical spine involvement in rheumatoid arthritis - A systematic review. Autoimmun Rev. 2014;13(12):1195-202. doi: 10.1016/j.autrev.2014.08.014.

19. Zhu S, Xu W, Luo Y, Zhao Y, Liu Y. Cervical spine involvement risk factors in rheumatoid arthritis: a meta-analysis. Int J Rheum Dis. 2017;20(5):541-9.

20. Mańczak M, Gasik R. Cervical spine instability in the course of rheumatoid arthritis imaging methods. Reumatologia. 2017;55(4):201-7. doi: 10.5114/reum.2017.69782.

21. Lipson SJ. Rheumatoid Arthritis of the Cervical Spine. Clin Orthop Relat Res. 1984;(182):143-9.

22. Yurube T, Sumi M, Nishida K, Miyamoto H, Kohyama K, Matsubara T, et al. Accelerated Development of Cervical Spine Instabilities in Rheumatoid Arthritis: A Prospective Minimum 5-Year Cohort Study. PLoS One. 2014;9(2):e88970. doi: 10.1371/journal.pone.0088970.

23. Kim HJ, Nemani VM, Riew KD, Brasington, R. Cervical Spine Disease in Rheumatoid Arthritis: Incidence, Manifestations, and Therapy. Curr Rheumatol Rep. 2015;17(2):9. doi: 10.1007/ s11926-014-0486-8.

24. Paus AC, Steen H, Røislien J, Mowinckel P, Teigland J. High Mortality Rate in Rheumatoid Arthritis With Subluxation of the Cervical Spine. Spine (Phila Pa 1976). 2008;33(21):227883. doi: 10.1097/BRS.0b013e31817f1a17.

25. lyer S, Lenke LG, Nemani VM, Fu M, Shifflett GD, Albert TJ, et al. Variations in Occipitocervical and Cervicothoracic Alignment Parameters Based on Age: A Prospective Study of Asymptomatic Volunteers Using Full-Body Radiographs. Spine (Phila Pa 1976). 2016;41(23):1837-44. doi: 10.1097/BRS.0000000000001644.

26. Nojiri K, Matsumoto M, Chiba K, Maruiwa H, Nakamura M, Nishizawa T, et al. Relationship Between Alignment of Upper and Lower Cervical Spine in Asymptomatic Individuals. J Neurosurg. 2003:99(1 Suppl):80-3. doi: 10.3171/spi.2003.99.1.0080

27. Lee SH, Son ES, Seo EM, Suk KS, Kim KT. Factors determining cervical spine sagittal balance in asymptomatic adults: correlation with spinopelvic balance and thoracic inlet alignment. Spine J. 2015;15(4):705-12. doi: 10.1016/j.spinee.2013.06.059

28. Yoshimoto H, Ito M, Abumi K, Kotani Y, Shono Y, Takada T, et al. A Retrospective Radiographic Analysis of Subaxial Sagittal Alignment After Posterior C1-C2 Fusion. Spine (Phila Pa 1976). 2004;29(2):175-81. doi: 10.1097/01.BRS.0000107225.97653.CA

29. Matsunaga S, Onishi T, Sakou T. Significance of Occipitoaxial Angle in Subaxial Lesion After Occipitocervical Fusion. Spine (Phila Pa 1976). 2001;26(2):161-5. doi: 10.1097/00007632-200101150-00010

30. Duval-Beaupère G, Schmidt C, Cosson P. A Barycentremetric study of the sagittal shape of spine and pelvis: the conditions required for an economic standing position. Ann Biomed Eng. 1992;20(4):451-62.

31. Berthonnaud E, Dimnet J, Roussouly P, Labelle H. Analysis of the sagittal balance of the spine and pelvis using shape and orientation parameters. J Spinal Disord Tech. 2005;18(1):40 7. doi: 10.1097/01.bsd.0000117542.88865.77.

32. Legaye J, Duval-Beaupère G. Hecquet J, Marty C. Pelvic incidence: a fundamental pelvic parameter for 3D regulation of spinal sagittal curves. Eur Spine J. 1998;7(2):99-103. doi: $10.1007 / \mathrm{s} 005860050038$ 